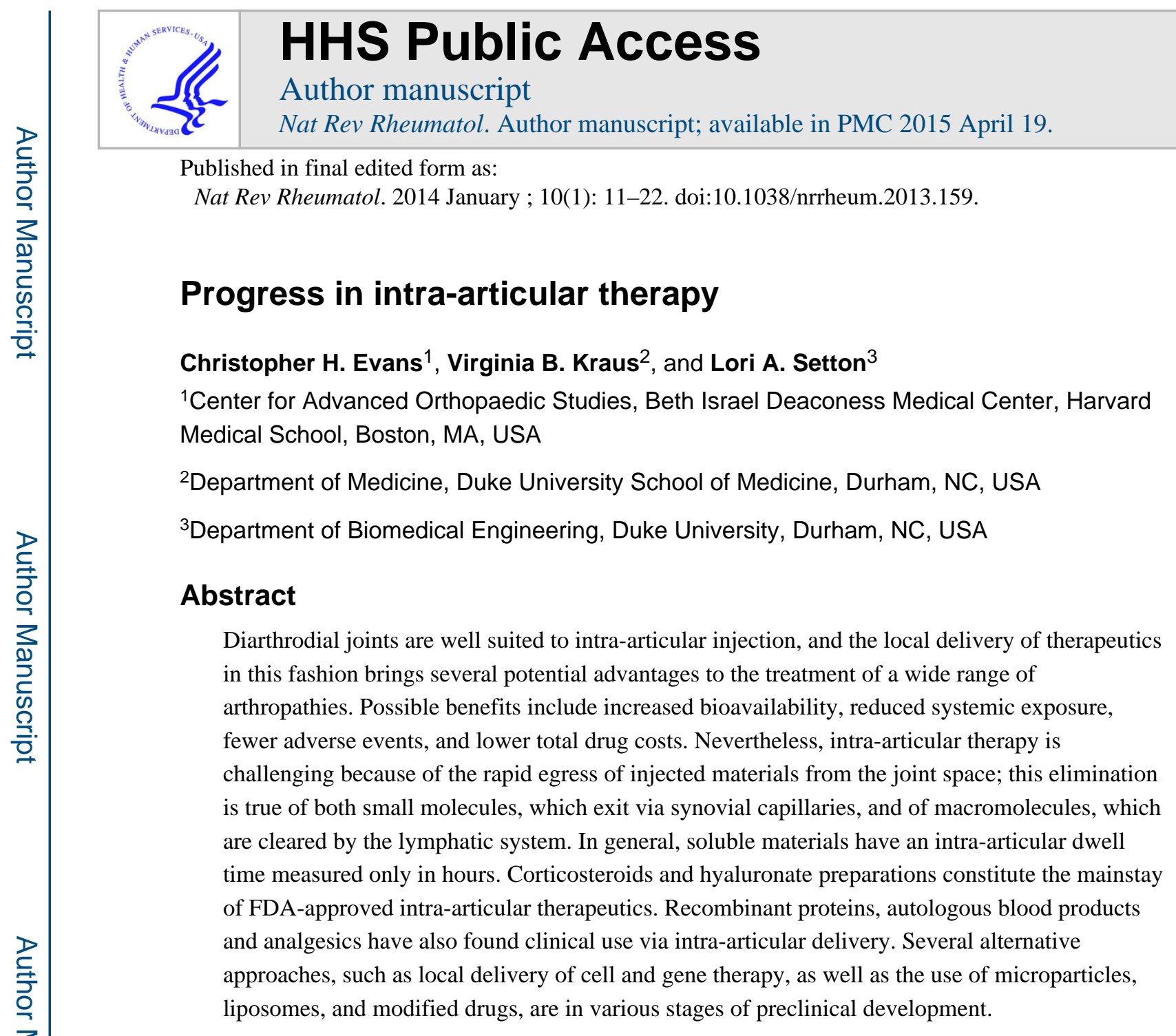

\title{
Introduction
}

For a drug with a direct mode of action, local administration offers several advantages over systemic delivery, including increased bioavailability, reduced systemic exposure, fewer offtarget effects and adverse events, and lower total drug cost. Being discrete cavities, most diarthrodial joints are well suited to local drug delivery via intra-articular injection.

Osteoarthritis (OA), which affects individual joints, and polyarticular inflammatory pathologies, including rheumatoid arthritis (RA) and gout, have high incidence and longterm therapeutic need; moreover, current treatment options are inadequate for many patients. Thus, tremendous interest has been generated in achieving successful localization of therapeutics at the pathological site, to maximize efficacy and reduce drug cost. Most common disorders of diarthrodial joints—-with RA the exception—are not accompanied by

\footnotetext{
Correspondence to: C.H. Evans, PhD, Center for Advanced Orthopaedic Studies, Beth Israel Deaconess Medical Center, 330, Brookline Avenue, RN-115, Boston, MA, 02215, cevans@ bidmc.harvard.edu.

Competing interests

C. H. Evans declares that he acts as a consultant for TissueGene Inc. and holds stock in Orthogen AG. L. A. Setton declares that she holds stock in PhaseBio. V. B. Kraus declares that she has received Royalties from PhaseBio.

(NB, statement provided in online manuscript tracking system says: "CHE: Board of Directors, Orthogen AG Scientific Advisory Board, TissueGene Inc. LAS: Holds stock in PhaseBio VBK: Has received royalties from PhaseBio I need to ask VBK and LAS").
} 
clinically significant extra-articular manifestations, which makes the prospect of local therapy particularly appealing. Reflecting the growing interest in this field, the second International Symposium on Intra-Articular Treatment will be held in Barcelona in October 2013. ${ }^{126}$

This Review discusses therapeutics that can be comfortably introduced into the joint in an outpatient setting via a small-gauge needle. Arthroscopy and other surgical procedures are, therefore, excluded. First, we describe how the biology of the joint controls the entry and clearance of exogenous molecules. Next, we outline current uses of intra-articular therapy in rheumatology and orthopaedics. Finally, we consider the development of emerging strategies such as drug-delivery particles, gene transfer and cell-based therapies.

\section{The pharmacokinetics of the joint}

The joint-space 'dwell time' of a therapeutic agent is influenced by the rate at which the molecule reaches and is cleared from the synovial fluid. The former parameter depends on the size and route of administration of the drug, whereas the rate of efflux of a soluble agent is largely independent of these properties (Figure 1). Systemically delivered, soluble substances enter the joint space via the capillary network of the sub-synovium, which is highly vascularized; small molecules also leave via the vasculature whereas larger substances such as proteins exit via the lymphatic system. ${ }^{1}$

\section{Drug delivery to cartilage}

For certain indications, it is necessary to deliver therapeutics to cartilage. Because cartilage is avascular, it is inefficiently targeted by systemic delivery of drugs, which must first reach the synovial fluid and then diffuse through the cartilagenous extracellular matrix (ECM). Unless damaged, this matrix is highly anionic and increasingly impermeable to molecules much greater than the size of albumin ( 67,000 Da), depending upon their charge and conformation. ${ }^{127}$ Intra-articular therapy improves delivery to cartilage and can thus increase therapeutic efficacy, but in doing so it exposes chondrocytes to higher concentrations of drugs. In developing intra-articular therapeutics, therefore, investigators must be aware of the potential for exposing previously unrecognized chondrotoxicity.

\section{Joint-space entry is size-dependent}

To enter the joint space from the synovial circulation, solutes need to pass through two layers of resistance in series: the capillary wall and the ECM of the synovial intima. ${ }^{2}$ The endothelial lining of the subsynovial capillaries is fenestrated, with the fenestrations orientated towards the joint space; this orientation facilitates the directed exit of solutes from these capillaries. Because the synovium has no basement membrane to impede molecular transit ${ }^{3}$, small molecules pass freely through the vascular endothelium, and the major determinant of their entry into the joint space is their rate of diffusion through the synovial interstitium. With this entry route being dependent on the small pores of the capillary endothelium and the tight spaces of the interstitial matrix, unimpeded transport through passive diffusion occurs only for small molecular weight compounds, typically <10 kDa. 
For larger molecules, the endothelial lining imposes a size-dependent sieving effect on the rate of passage (Figure 2). For example, the concentration ratio of normal synovial fluid:serum for albumin (which is $67 \mathrm{kDa}$ ) is $\sim 0.40$; for the much larger molecules a2macroglobulin and $\mathrm{IgG}$ this ratio drops to $0.03-0.05 .{ }^{4}$ Fibrinogen, with a MW of $340 \mathrm{kDa}$, is rarely found in synovial fluid in the absence of inflammation, probably because of its very high Stokes radius (that is, hydrodynamic radius). ${ }^{4}$

\section{Inflammation increases synovial permeability}

Synovial inflammation is a key feature of many joint pathologies; most notably observed in RA and following joint injury, it is also present in OA. ${ }^{5}$ In an inflamed joint, capillary permeability increases, thereby enhancing the entry of macromolecules into the joint space. Evidence of this effect can be found in the protein content of synovial fluid from patients with RA, which is increased in comparison with healthy controls, as well as notable increases in the proportion of large to small molecular components in RA samples. ${ }^{4,6}$

\section{Macromolecules have short dwell time}

Although entry of macromolecules into joints is constrained, their removal from joints occurs via the lymphatic system in a fashion that, unlike their entry, is independent of size (Figure 1). The rate of removal of macromolecules from the joint is increased in patients with RA, reflecting enhanced drainage from the joint space due to greater synovial lymph flow. ${ }^{7}$

Because lymphatic drainage is highly efficient, the intra-articular dwell time of proteins in joints is typically a few hours or less. This timescale presents obvious problems when attempting to treat chronic joint disorders with large molecules. Although intra-articular injection can circumvent the entry restrictions imposed by synovial sieving (Figure 1), it cannot avoid rapid lymphatic clearance of a therapeutic agent. The need to increase intraarticular dwell time was a major reason why local gene delivery to joints was suggested as a therapeutic strategy ${ }^{8}$. Similar time constraints exist for small molecules, which rapidly diffuse from the joint via the synovial capillaries. Larsen et al. ${ }^{9}$ have tabulated the half-lives of various substances within the joints of experimental animals as well as within healthy and arthritic human joints. The values reported range from $0.23 \mathrm{~h}$ for acridine orange (MW 370 Da) to $1.23-13.1 \mathrm{~h}$ for albumin and $26.3 \mathrm{~h}$ for hyaluronic acid (MW $3 \times 10^{6} \mathrm{Da}$ ). Intra-joint half-lives of NSAIDs and soluble steroids cluster at around 1-4 h. ${ }^{9}$ These values illustrate the challenges facing intra-articular therapy, especially for chronic conditions.

\section{Intra-articular injection}

\section{Pros and cons versus systemic delivery}

Although various pro-drug ${ }^{10}$ and particle-based ${ }^{11}$ strategies for targeting drugs to inflamed joints through the systemic circulation are in development, intra-articular injection remains the method of choice for local therapeutic delivery. This route of administration overcomes concerns about the extent of bioavailability, unknown or uncontrollable drug dosing, the effects of drug binding to systemic molecules, and other drug modifications that can limit 
the efficacy of a substance administered via systemic delivery. Moreover, it eliminates many patient compliance issues.

Nevertheless, in many countries, intra-articular injections are performed almost exclusively by rheumatologists and orthopaedists; this requirement for specialist time is limiting when repetitive, serial injections are necessary. The exclusion of the general practitioner places intra-articular delivery at a logistical disadvantage compared with oral and selfadministered, subcutaneous administration. However, the development of technologies such as fluoroscopy and ultrasonography to ensure accuracy could expand the use of intraarticular injection to a wider spectrum of physicians.

\section{Clinical history}

Clinical use of intra-articular injections dates back to the 1930s when formalin, glycerin, lipodol, lactic acid and petroleum jelly were among the first substances injected into patients with arthritis. ${ }^{12}$ Widespread and persistent use of the technique began in the 1950s when intra-articular injections of corticosteroids became common for treating patients with RA. ${ }^{13}$ More recently, the use of intra-articular injections has expanded greatly with the approval of therapeutics based on hyaluronate for the treatment of OA (discussed later in this manuscript).

\section{Delivery and adverse events}

Accuracy of injection is an issue, even for large, accessible joints such as the knee where as many as 50\% of intended intra-articular injections by experienced physicians can end up in extra-articular locations ${ }^{14,15}$. Nevertheless, Simkin ${ }^{16}$ has argued that, because the synovial fluid is contiguous with the interstitial fluid of the synovium, any injection within the joint capsule is close enough to the target site. Accuracy is improved by fluoroscopic and ultrasound guidance techniques, and these tools are particularly valuable for treating joints, such as the hip, that are difficult to access.

Other than injection-site reactions in certain individuals, little morbidity is associated with intra-articular injection of corticosteroids or hyaluronic acid, the main concern being infection. Incidences of 1 in 3,000 to 1 in 50,000 have been reported in the literature ${ }^{17}$. Although these rates are low, the increased cumulative risk of infection with repeat administration and concern about possible adverse effects of corticosteroids on cartilage create reluctance to inject joints too frequently. No rigid guidelines on this matter exist, but most practitioners are reluctant to inject a joint more than once every 3-6 months, unless delivering agents such as hyaluronic acid, which require multiple injections.

\section{Intra-articular therapeutics}

\section{Corticosteroids}

A long history of intra-articular corticosteroid use exists for patients with RA ${ }^{13}$. Although the introduction of TNF antagonists has reduced the need for intra-articular corticosteroids in this disease, they are still administered to individual symptomatic joints that fail to respond to systemically delivered drugs. 
Joint-space kinetics—Corticosteroids are highly hydrophobic, small (<700Da) hydrocarbons that can be transported into the joint space after systemic administration through trans-capillary diffusion, although resulting bioavailability in the synovial fluid is much reduced in comparison with the systemic compound. Thus, one motivation for developing intra-articular delivery of corticosteroids has been to increase effective dosing. Besides increasing the rate of entry to the joint, intra-articular injection also enables delivery of modified molecules that would be incompatible with systemic delivery—such modifications can increase the intra-joint retention of corticosteroid formulations. Drug clearance is thus reduced through the use of excipients (for example, polyethylene glycol, dextran or polysorbate-based suspension) that promote retention of the drug in an aqueous solution, or salts that promote retention of the steroid in a crystalline form over long periods of time. In this manner, the drugs are complexed with salts or polymers and suspended in aqueous solutions that act to sequester the drug from the synovial fluid and delay clearance from the joint space ${ }^{18,19}$. Nevertheless, the intra-articular half-lives achieved for corticosteroids have rarely been found to exceed 12 hours, owing to the very low molecular weights of these compounds. ${ }^{19}$

Roles in rheumatology and orthopaedics-Intra-articular corticosteroids are a mainstay of therapy in $\mathrm{OA}^{20}$ and are typically reserved for joints with refractory pain and/or effusion. Although pain and other symptoms are reduced for up to 4 weeks following injection, ${ }^{20}$ there is concern that prolonged exposure to steroids might adversely affect articular cartilage and thus accelerate the progress of the disease. For this reason, many physicians limit the use of corticosteroids to 3-4 intra-articular injections annually into any given joint with OA.

Corticosteroids are also administered for gout, and for treating many other circumstances where the joint is painful or inflamed. Their use after injury to the joint to prevent the development of post-traumatic OA might also be possible; the results of a cartilage-explant study published in 2013 indicate that short-term glucocorticoid therapy might prevent the catabolic consequences of mechanical injury and proinflammatory cytokines. ${ }^{21}$

Formulation and use-A number of different corticosteroid formulations are available for intra-articular injection (Box 1). Few studies have compared their effectiveness; those that have done so suggest that triamcinolone hexacetonide might be of greater benefit than other preparations in $\mathrm{RA}^{128,129}$ juvenile idiopathic arthritis ${ }^{22}$ and in $\mathrm{OA},{ }^{23}$ perhaps because it is least soluble

Several studies have suggested that intra-articular glucocorticoid injection for knee synovitis has a better outcome in resting patients than in mobile patients. Nevertheless, on the basis of objective measures of serum levels of triamcinolone hexacetonide, cortisol and adrenocorticotropic hormone, immobilization does not seem to retard glucocorticoid resorption after intra-articular administration. ${ }^{24}$

\section{Hyaluronate}

Intra-articular administration of the ECM component hyaluronate is very common for the treatment of pain in joints with OA that has not responded to NSAIDs or analgesics such as 
acetaminophen. Seven different hyaluronate preparations have been approved by the FDA for injection into the knee (Box 1); a growing literature also investigates their use in other joints such as the hip, shoulder, facet joint and the small joints of the hands and feet ${ }^{25}$.

Joint-space kinetics-Unmodified hyaluronate reportedly resides within the joint space for $12-24 \mathrm{~h}$ following intra-articular delivery. ${ }^{26}$ Historically presumed to be the main lubricant of the joint hyaluronate is believed to act as a viscosupplement following intraarticular injection, replacing or supplementing the endogenous molecule. ${ }^{130}$ As such, its longevity and persistence within the joint space are crucial to its function, which depends on its physical presence. Thus, investigators are developing very high molecular weight, or crosslinked, hyaluronate preparations that can reportedly contribute to intra-articular halflives exceeding $48 \mathrm{~h}$ in animal studies $;{ }^{27}$ crosslinked preparations are also in clinical use (Box 1).

Clinical performance and development-Given the frequency of OA and the current lack of disease-modifying therapies, intra-articular injections of hyaluronate are widely used and represent one of the most common reasons for intra-articular injection. However, opinion remains divided on their efficacy and considerable divergence is reported in the literature, including in the contrasting results of meta-analyses. ${ }^{28,29}$ Potentially, improved understanding of how ECM molecules such as hyaluronate influence the intra-articular pathophysiology of the joint in OA will lead to more effective alternatives. Indeed, interest is high in the possible intra-articular application of another lubricating macromolecule, lubricin, for the treatment of OA. ${ }^{30}$ Lubricin, also known as proteoglycan 4 , is thought to be particularly important for cartilage-on-cartilage lubrication and to be more effective than hyaluronic acid in this regard. Its absence in humans with the disease camptodactylylarthropathy-coxavara-pericarditis syndrome ${ }^{131}$ or knock-out mice ${ }^{132}$ leads to cartilage degeneration. Intra-articular injection of lubricin prevents the development of post-traumatic OA in rats. ${ }^{133}$

\section{Biologic agents}

Joint-space kinetics of proteins-The success of infliximab, etanercept, adalimubab and other anti-TNF agents as systemic treatments for RA has led to their intra-articular use in individual joints that do not respond to systemic therapy. ${ }^{31}$ Other recombinant proteins, such as the IL-1 receptor antagonist anakinra and the anti-IL- $1 \beta$ monoclonal antibody canakinumab have followed suit and are being trialled as joint injections (Table 1). These agents are typically soluble proteins of with kinetics of joint clearance that, in line with the discussion in the "Pharmokinetics of the joint" section, can be expected to be approximately 2-4 h.

Systemic vs intra-articular anti-TNF agents-Clinical trials of joint injections of the TNF antagonist etanercept have been pursued for the treatment of both RA and refractory knee joint synovitis (Table 1). Similarly, intra-articular delivery of infliximab for the treatment of OA and spondyloarthritis has been compared with intravenous delivery of the biologic agent or corticosteroid. Although no randomized controlled trial has been performed, anecdotal reports indicate outcomes of success in treating spondyloarthritis, RA 
and OA. ${ }^{33-35}$ However, intra-articular delivery of proteinaceous anti-TNF agents has not become a mainstay of clinical care.

Clinical progress with other proteins-Recombinant interleukin-1 receptor antagonist (rIL-1Ra; anakinra) has been evaluated as an intra-articular treatment for OA. Despite the encouraging results of an open-label pilot study, ${ }^{36}$ a subsequent phase II study showed only short-term benefit. ${ }^{37}$ This finding might reflect the rapid egress of rIL-1Ra, a $17 \mathrm{kDa}$ protein, from the joint. Nevertheless, a single, intra-articular injection of anakinra immediately after injury prevented post-traumatic OA in a mouse fracture model of the disease. ${ }^{38}$ Of interest, the same dose administered daily for 1 month by subcutaneous osmotic pump had no effect. In a phase I clinical study, intra-articular injection of anakinra improved short-term outcomes after rupture of the anterior cruciate ligament. ${ }^{39}$ As for TNF antagonists and any new indication, the time, amount and dosing to achieve a therapeutic concentration in the joint space, albeit for a short duration, are critical but unknown variables.

Intra-articular delivery of bone morphogenetic protein 7 (BMP7) showed promising results in a phase I clinical study in patients with OA of the knee, ${ }^{41}$ but data from the subsequent phase II trial have not yet been published. ${ }^{97}$ Fibroblast growth factor 18 (FGF18) and canakinumab are also in current clinical trials testing their efficacy as intra-articular treatments for OA (Table 1).

\section{Autologous blood products}

Platelet-rich plasma (PRP) is widely used by the orthopaedic community as a treatment for a variety of musculoskeletal problems, including OA, despite scant solid evidence to commend this approach. ${ }^{134} \mathrm{~A}$ few case reports and small clinical series in which PRP has been injected into joints with OA have been published; however, the results are equivocal and much more research is needed. ${ }^{42}$ Clinical experiences are difficult to compare, because different preparations of PRP have different compositions and variable effects on inflammation. ${ }^{43}$ A concentrated PRP product known as Autologous Protein Solution is being evaluated in patients with $\mathrm{OA}^{140}$.

Autologous conditioned serum is obtained from incubated blood and injected into joints with OA or other painful conditions. Whole blood is incubated with medical-grade, etched glass beads that induce the synthesis of anti-inflammatory molecules, including IL-1Ra. ${ }^{44}$ After filtration, the conditioned serum is injected into the joint. Apart from rare cases of acute inflammation after intra-articular administration of this complex preparation, the overall incidence of complications seems to be low. ${ }^{45}$ A randomized controlled clinical trial in 376 patients with knee OA demonstrated a therapeutic effect superior to that achieved with the injection of saline or hyaluronic acid. ${ }^{46}$

\section{Analgesics}

Local anaesthetics have FDA approval as injections for the production of local or regional anaesthesia or analgesia. Intra-articular analgesia is often used after joint surgery and occasionally in joints with OA. Lidocaine, bupivacaine, ropivacaine, opiates and have been 
evaluated as intra-articular analgesics, mostly for post-operative pain ${ }^{12}$, Botulinum toxin A has been evaluated as a therapy for chronic joint pain and $\mathrm{OA}^{47}$ Chondrolysis associated with the use of intra-articular local anaesthetic 'pain pumps' has been described by several groups, ${ }^{48-50}$ which has raised concern about the clinical use of intra-articular anaesthetics. Dose-dependent toxic effects of analgesics, including apoptosis, have been demonstrated in vitro. ${ }^{51}$ The type and concentration of anaesthetic, as well as additives and $\mathrm{pH}$, have been implicated in the chondrotoxicity of intra-articular analgesics. ${ }^{51,52}$ Ropivocaine is less toxic in cultured chondrocytes and cartilage explant systems than bupivacaine. ${ }^{52}$

\section{Intra-articular drug delivery systems}

As we have mentioned, low molecular weight compounds are cleared rapidly from the joint space. Furthermore, poor drug solubility and poor tissue distribution within the joint have helped to create interest in designing drug delivery systems specifically for the intraarticular environment. As we discuss here, liposomes and microparticles have consequently been evaluated in the context of intra-articular drug delivery.

Liposomes-Liposomes entrap primarily hydrophobic drugs in a lipid bilayer or lipid phase, and provide for sustained release through liposome dissolution and slow solubilization of the drug. Liposome drug-loading efficiencies as high as $90 \%$ are possible for many hydrophobic drugs and these vesicles are thus attractive for delivering corticosteroids such as triamcinolone, celocoxib, dexamethasone, and cortisol-21palmitate. ${ }^{53-55}$ The longevity of the drug and its onset of action are dependent upon particle size, with results suggesting that liposomes can extend drug activity by as much as 14 days. ${ }^{53}$ This pharmacodynamic extension might be attributable to efficient endocytosis of the liposome and/or to prolonged drug re-solubilization. Particle sizes of $100 \mathrm{~nm}-5 \mu \mathrm{m}$ seem to be suitable for achieving prolonged drug retention, with too rapid clearance of drug from liposomes noted for much smaller particles. ${ }^{9,135}$

Liposomes are less useful with more polar drugs, such as methotrexate, because of low drug loading ratios and a rapid burst release encountered in the aqueous environment of the synovial fluid..$^{9,135}$ Moreover, liposomal preparations require mixing of the drug with organic solvents that are damaging to proteinaceous drugs. Nevertheless, several therapeutic liposomal formulations are in clinical use for a variety of indications, including the delivery of doxorubicin in cancer (for example, Doxil ${ }^{\mathrm{TM}}$, Janssen Biotech), amphotericin for fungal infection (for example, AmBisome ${ }^{\mathrm{TM}}$, Astellas Pharma) and cytarabine for cancer (Depocyt ${ }^{\circledR}$, Sigma-tau Pharma), with good safety profiles that suggest their potential utility for localized intra-articular delivery. Knowledge of these liposomal formulations applies, however, to intravenous, topical or intramuscular use, with only one liposomal product available for intra-articular delivery, a palmitylated dexamethasone, and only in Germany (Lipotalon®, Merckle).

Microparticles and nanoparticles-For proteinaceous drugs and polar molecules, synthetic polymeric microparticles and nanoparticles might be more suitable than liposomes as drug delivery systems for the joint space. Biodegradable microparticles composed of polyesters (for example, PGLA, PLLA), polyanhydrides, and polycaprolactones have been 
developed for broader clinical applications, including the encapsulation of synthetic hormones (Lupron $®$, Abbott), tretinoin (RetinA Micro®, OrthoNeutrogena) and risperidone (Riseperdal ${ }^{\circledR}$, Janssen Pharma) and have shown potential for prolonging intra-articular drug residence time in preclinical studies. For betamethasone ${ }^{56,58}$, methotrexate ${ }^{60}$, diclofenac ${ }^{59}$, siRNA ${ }^{136}$ and paclitaxel, ${ }^{57}$ for example, encapsulation in microspheres composed of PLLA, PLGA, or polycaprolactones contributed to a sustained release effect in animal models of arthritis that could be observed up to 21 days after delivery in some cases. ${ }^{56-60}$

Drug availability within the joint space following delivery within a microsphere depends on the competing and synergistic processes of drug diffusion from the polymer, erosion of the polymeric microparticle, and size-dependent endocytosis of the particle. As with liposomes, microparticles of a range of sizes can seemingly be endocytosed without provoking deleterious inflammation (generally particles $<30 \mathrm{~mm}$ ), and a lower size limit exists below which little benefit of particulation is noted $(50 \mathrm{~nm})$. Drugs have also been studied following encapsulation in naturally derived polymeric materials, including chitosan microspheres, albumin, gelatin, elastin-based systems and collagen. Overall, particle-based delivery systems have the potential to increase drug residence times greatly, with 10-30-fold increases reported in pre-clinical models. A clinical study reported in 2013 of a PGLAencapsulated corticosteroid, triamcinolone acetonide (FX006, Flexion Therapeutics), demonstrated residence in the joint space at therapeutic concentrations at 6 weeks after injection, ${ }^{137}$ providing some evidence of even longer periods of sustained release for microcapsules. Nevertheless, no particle-based or liposome drug-delivery system has yet advanced past clinical trials for intra-articular drug delivery in the USA, possibly because of the need to establish cost-effective manufacturing processes and dosing strategies.

\section{Modifying drugs to increase dwell time}

Direct modification of known drugs is a widely used strategy to prolong their residence time in the joint. Conjugation of a polyethylene glycol (PEG) moiety to a drug-PEGylation-is a frequently used method to increase the bioavailability of hydrophobic drugs and increase their molecular weight towards the goal of delaying systemic elimination. Similarly, a thermally responsive small polypeptide, elastin-like polypeptide (ELP), has been conjugated to protein drugs in a process called ELPylation. ${ }^{62}$ ELPylation leads to the temperaturecontrolled formation of a drug depot at the site of injection that has the potential to decrease drug clearance from the injection site. ELP has been conjugated to multiple drugs including TNF and IL-1 antagonists ${ }^{63,64}$ for application to intra-articular or perineural delivery. This approach has the potential to provide a 20 -fold increase in intra-articular drug residence time ${ }^{32}$ but is complicated by involving the creation of a novel conjugate, rather than an entrapped drug, with pharmacokinetics and pharmacodynamics that are not thoroughly studied.

\section{Nonsurgical synovectomy with radionuclides}

When particles of phagocytosable size are injected into joints they are taken up by macrophages present in the synovium. This process has been used to achieve nonsurgical synovectomy via the incorporation of radioactive materials in small particles, suspensions of which are injected into the joint. The technique is used for chronic synovial conditions, such 
as diffuse pigmented villonodular synovitis and the haemorthrosis of patients with haemophilia, that are difficult to treat by other means. Historically a common treatment for RA, radioactive synovectomy has also been evaluated in OA. ${ }^{65}$ Improvements in pain and inflammation were noted, with the greatest effects seen in knees with the least radiologic evidence of damage. Isotopes of the lanthanide series of elements, such as $\mathrm{Y}^{90}, \mathrm{Sm}^{153}, \mathrm{Er}^{169}$ and $\mathrm{Yb}^{175}$, are particularly suited to this purpose and their use has supplanted chemical synovectomy as the nonsurgical method of choice. ${ }^{66}$ Although radiation synovectomy is rarely used for OA or RA, it is a method of choice for haemophilic synovitis. ${ }^{138}$ Radiation synovectomy is complicated by rare cutaneous radiation necrosis ${ }^{67}$ and concerns about genotoxic effects. ${ }^{6}$

\section{Gene therapy}

Local gene transfer to the joint provides one solution to the problem of maintaining a sustained, therapeutic concentration of a gene product within a diseased joint, and can be accomplished by administration of cells genetically modified ex vivo ${ }^{69}$ or by the direct, intra-articular injection of viral or non-viral vectors. ${ }^{70}$ Intra-articular gene therapy—as reviewed in this journal in $2011^{72}$ - has been evaluated in phase I clinical trials in patients with RA and OA. A phase II study in RA, using adeno-associated virus to deliver etanercept, was marred by the death of one of the study subjects but was allowed to proceed to completion. ${ }^{71}$ Phase II trials in OA, using allogeneic cells expressing transforming growth factor $\beta_{1}$, are continuing in Korea and the USA. ${ }^{72}$

\section{Cell-based therapies}

The first clinical use of intra-articular cell delivery was in the context of gene therapy, using genetically modified, autologous synovial fibroblasts (Table 2). ${ }^{69}$ Since then, chondrocytes and blood cells have been injected into human joints (Table 2), but by far the greatest activity surrounds the use of mesenchymal stem cells (MSCs). Their use has increased spectacularly in the past 3 years: 31 trials are listed in Table 2; 23 of them involve MSCs and, of these, 20 were registered on ClinicalTrials.gov from 2010 onwards.

As described by Barry and Murphy in this journal, ${ }^{139}$ the potential intra-articular use of MSCs in treating OA has attracted considerable attention because MSCs are thought to be anti-inflammatory and immunosuppressive mediators of tissue regeneration. ${ }^{73-75}$ Encouraging preclinical data have emerged ${ }^{76-78}$ in relation to preventing post-traumatic OA, regenerating damaged cartilaginous surfaces and reducing pain. The intra-articular injection of MSCs derived from bone marrow or fat is widely used in equine medicine for the treatment of OA and such therapies are commercially available for use in animals. Only a few small human clinical case series have been published, such as a study using autologous MSCs in four people with knee OA, ${ }^{79}$ with equivocal results. The immunosuppressive nature of MSCs introduces the possibility that they can be successfully allografted, which raises the prospect of developing a therapy from a universal donor; such a step would reduce the cost and complexity of generating approved treatments. 


\section{Conclusions}

The intra-articular injection of therapeutic agents is an attractive strategy for the local treatment of joint diseases. Most joints are accessible to accurate injection, especially when using image guidance. Given that such injections cannot be administered too frequently, it is preferable to use reagents that have a lasting therapeutic effect. However, soluble agents are rapidly cleared from joints, regardless of the size of the drug, and this transience remains a major barrier to successful therapy. Intra-articular injection became popular in the latter half of the twentieth century owing to the introduction of intra-articular corticosteroids. Today, this treatment and the injection of hyaluronate into joints with OA form the major uses of this technique. Interest in delivering recombinant proteins, autologous blood products, particles, cells and gene therapy vectors to diseased joints continues to mount. Local delivery in this fashion is potentially safer, less expensive and more effective than parenteral delivery. Reducing the need for burdensome repeated injections of soluble therapeutics will, however, require better drug formulations with more lasting efficacy.

\section{Acknowledgements}

The authors would like to acknowledge financial support from NIAMS in the form of the following grants: P01AR050245, R01AR047442, R01AR051085, X01 NS066865.

\section{References}

1. Simkin PA. Synovial perfusion and synovial fluid solutes. Ann Rheum Dis. 1995; 54:424-428. [PubMed: 7794054]

2. Simkin PA. Synovial permeability in rheumatoid arthritis. Arthritis Rheum. 1979; 22:689-696. [PubMed: 454497]

3. Knight AD, Levick JR. Morphometry of the ultrastructure of the blood-joint barrier in the rabbit knee. Q J Exp Physiol. 1984; 69:271-288. [PubMed: 6729017]

4. Kushner I, Somerville JA. Permeability of human synovial membrane to plasma proteins. Relationship to molecular size and inflammation. Arthritis Rheum. 1971; 14:560-570. [PubMed: 4106176]

5. Scanzello CR, Goldring SR. The role of synovitis in osteoarthritis pathogenesis. Bone. 51:249-257. [PubMed: 22387238]

6. Decker B, Mc KB, Mc GW, Slocumb CH. Comparative distribution of proteins and glycoproteins of serum and synovial fluid. Arthritis Rheum. 1959; 2:162-177. [PubMed: 13638177]

7. Wallis WJ, Simkin PA, Nelp WB. Protein traffic in human synovial effusions. Arthritis Rheum. 1987; 30:57-63. [PubMed: 3814198]

8. Bandara G, et al. Gene transfer to synoviocytes: prospects for gene treatment of arthritis. DNA Cell Biol. 1992; 11:227-231. [PubMed: 1567555]

9. Larsen $\mathrm{C}$, et al. Intra-articular depot formulation principles: role in the management of postoperative pain and arthritic disorders. J Pharm Sci. 2008; 97:4622-4654. [PubMed: 18306275]

10. Yuan F, Quan LD, Cui L, Goldring SR, Wang D. Development of macromolecular prodrug for rheumatoid arthritis. Adv Drug Deliv Rev.

11. Anderson R, et al. Liposomal encapsulation enhances and prolongs the anti-inflammatory effects of water-soluble dexamethasone phosphate in experimental adjuvant arthritis. Arthritis Res Ther. 12:R147. [PubMed: 20642832]

12. Lavelle W, Lavelle ED, Lavelle L. Intra-articular injections. Anesthesiol Clin. 2007; 25:853-862. viii. [PubMed: 18054149] 
13. Hollander JL, Brown EM Jr, Jessar RA, Brown CY. Hydrocortisone and cortisone injected into arthritic joints; comparative effects of and use of hydrocortisone as a local antiarthritic agent. J Am Med Assoc. 1951; 147:1629-1635. [PubMed: 14880415]

14. Jackson DW, Evans NA, Thomas BM. Accuracy of needle placement into the intra-articular space of the knee. J Bone Joint Surg Am. 2002; 84-A:1522-1527. [PubMed: 12208907]

15. Jones A, et al. Importance of placement of intra-articular steroid injections. BMJ. 1993; 307:13291330. [PubMed: 8257889]

16. Simkin PA, et al. When is a joint injection accurate? Comment on the article by Cunnington. Arthritis Rheum. 63:308. author reply 308. [PubMed: 20954259]

17. Charalambous CP, Tryfonidis M, Sadiq S, Hirst P, Paul A. Septic arthritis following intra-articular steroid injection of the knee--a survey of current practice regarding antiseptic technique used during intra-articular steroid injection of the knee. Clin Rheumatol. 2003; 22:386-390. [PubMed: 14677011]

18. Armstrong RD, English J, Gibson T, Chakraborty J, Marks V. Serum methylprednisolone levels following intra-articular injection of methylprednisolone acetate. Ann Rheum Dis. 1981; 40:571574. [PubMed: 7332377]

19. Derendorf H, Mollmann H, Gruner A, Haack D, Gyselby G. Pharmacokinetics and pharmacodynamics of glucocorticoid suspensions after intra-articular administration. Clin Pharmacol Ther. 1986; 39:313-317. [PubMed: 3948470]

20. Creamer P. Intra-articular corticosteroid treatment in osteoarthritis. Curr Opin Rheumatol. 1999; 11:417-421. [PubMed: 10503664]

21. Lu YC, Evans CH, Grodzinsky AJ. Effects of short-term glucocorticoid treatment on changes in cartilage matrix degradation and chondrocyte gene expression induced by mechanical injury and inflammatory cytokines. Arthritis Res Ther. 13:R142. [PubMed: 21888631]

22. Zulian F, et al. Comparison of intra-articular triamcinolone hexacetonide and triamcinolone acetonide in oligoarticular juvenile idiopathic arthritis. Rheumatology (Oxford). 2003; 42:1254 1259. [PubMed: 12810938]

23. Hepper CT, et al. The efficacy and duration of intra-articular corticosteroid injection for knee osteoarthritis: a systematic review of level I studies. J Am Acad Orthop Surg. 2009; 17:638-646. [PubMed: 19794221]

24. Weitoft T, Ronnblom L. Glucocorticoid resorption and influence on the hypothalamic-pituitaryadrenal axis after intra-articular treatment of the knee in resting and mobile patients. Ann Rheum Dis. 2006; 65:955-957. [PubMed: 16769782]

25. Colen S, Haverkamp D, Mulier M, van den Bekerom MP. Hyaluronic acid for the treatment of osteoarthritis in all joints except the knee: what is the current evidence? BioDrugs. 26:101-112. [PubMed: 22385405]

26. Fraser JR, Kimpton WG, Pierscionek BK, Cahill RN. The kinetics of hyaluronan in normal and acutely inflamed synovial joints: observations with experimental arthritis in sheep. Semin Arthritis Rheum. 1993; 22:9-17. [PubMed: 8342053]

27. Larsen NE, Dursema HD, Pollak CT, Skrabut EM. Clearance kinetics of a hylan-based viscosupplement after intra-articular and intravenous administration in animal models. J. Biomed. Mater. Res. B Appl. Biomater. http://dx.doi.org/10.1002/jbm.b.31971.

28. Bannuru RR, Natov NS, Dasi UR, Schmid CH, McAlindon TE. Therapeutic trajectory following intra-articular hyaluronic acid injection in knee osteoarthritis--meta-analysis. Osteoarthritis Cartilage. 19:611-619. [PubMed: 21443958]

29. Rutjes AW, et al. Viscosupplementation for Osteoarthritis of the Knee: A Systematic Review and Meta-analysis. Ann Intern Med.

30. Jay GD, et al. Prevention of cartilage degeneration and restoration of chondroprotection by lubricin tribosupplementation in the rat following anterior cruciate ligament transection. Arthritis Rheum. 62:2382-2391. [PubMed: 20506144]

31. Fisher BA, Keat A. Should we be using intraarticular tumor necrosis factor blockade in inflammatory monoarthritis? J Rheumatol. 2006; 33:1934-1935. [PubMed: 17014012]

32. Betre $\mathrm{H}$, et al. A thermally responsive biopolymer for intra-articular drug delivery. J Control Release. 2006; 115:175-182. [PubMed: 16959360] 
33. Sakellariou GT, Kakavouli G, Chatzigiannis I. Intraarticular injection of infliximab. J Rheumatol. 2006; 33:1912-1913. author reply 1913. [PubMed: 16960955]

34. Fioravanti A, Fabbroni M, Cerase A, Galeazzi M. Treatment of erosive osteoarthritis of the hands by intra-articular infliximab injections: a pilot study. Rheumatol Int. 2009; 29:961-965. [PubMed: 19198842]

35. Fiocco U, et al. Synovial effusion and synovial fluid biomarkers in psoriatic arthritis to assess intraarticular tumor necrosis factor-alpha blockade in the knee joint. Arthritis Res Ther. 12:R148. [PubMed: 20642840]

36. Chevalier X, et al. Safety study of intraarticular injection of interleukin 1 receptor antagonist in patients with painful knee osteoarthritis: a multicenter study. J Rheumatol. 2005; 32:1317-1323. [PubMed: 15996071]

37. Chevalier X, et al. Intraarticular injection of anakinra in osteoarthritis of the knee: a multicenter, randomized, double-blind, placebo-controlled study. Arthritis Rheum. 2009; 61:344-352. [PubMed: 19248129]

38. Mangiapani DS, et al. Inhinition of interleukin-1 prevents post-traumatic arthritis following intrsaarticular fracture in the mouse knee. Trans Orthop Res Soc. 2012

39. Kraus VB, et al. Effects of intraarticular IL1-Ra for acute anterior cruciate ligament knee injury: a randomized controlled pilot trial (NCT00332254). Osteoarthritis Cartilage. 20:271-278. [PubMed: 22273632]

40. So A, De Smedt T, Revaz S, Tschopp J. A pilot study of IL-1 inhibition by anakinra in acute gout. Arthritis Res Ther. 2007; 9:R28. [PubMed: 17352828]

41. Hunter DJ, et al. Phase 1 safety and tolerability study of BMP-7 in symptomatic knee osteoarthritis. BMC Musculoskelet Disord. 11:232. [PubMed: 20932341]

42. Spakova T, Rosocha J, Lacko M, Harvanova D, Gharaibeh A. Treatment of knee joint osteoarthritis with autologous platelet-rich plasma in comparison with hyaluronic acid. Am J Phys Med Rehabil. 91:411-417. [PubMed: 22513879]

43. Dragoo JL, et al. Comparison of the acute inflammatory response of two commercial platelet-rich plasma systems in healthy rabbit tendons. Am J Sports Med. 40:1274-1281. [PubMed: 22495144]

44. Meijer H, Reinecke J, Becker C, Tholen G, Wehling P. The production of anti-inflammatory cytokines in whole blood by physico-chemical induction. Inflamm Res. 2003; 52:404-407. [PubMed: 14520515]

45. Fox BA, Stephens MM. Treatment of knee osteoarthritis with Orthokine-derived autologous conditioned serum. Expert Rev Clin Immunol. 6:335-345. [PubMed: 20441419]

46. Baltzer AW, Moser C, Jansen SA, Krauspe R. Autologous conditioned serum (Orthokine) is an effective treatment for knee osteoarthritis. Osteoarthritis Cartilage. 2009; 17:152-160. [PubMed: 18674932]

47. Boon AJ, et al. Efficacy of intra-articular botulinum toxin type A in painful knee osteoarthritis: a pilot study. PM R. 2:268-276. [PubMed: 20430328]

48. Piper SL, Kramer JD, Kim HT, Feeley BT. Effects of local anesthetics on articular cartilage. Am J Sports Med. 39:2245-2253. [PubMed: 21515808]

49. Dragoo JL, Braun HJ, Kim HJ, Phan HD, Golish SR. The in vitro chondrotoxicity of single-dose local anesthetics. Am J Sports Med. 40:794-799. [PubMed: 22287644]

50. Chu CR, et al. In vivo effects of single intra-articular injection of $0.5 \%$ bupivacaine on articular cartilage. J Bone Joint Surg Am. 92:599-608. [PubMed: 20194318]

51. Grishko V, Xu M, Wilson G, Pearsall AWt. Apoptosis and mitochondrial dysfunction in human chondrocytes following exposure to lidocaine, bupivacaine, and ropivacaine. J Bone Joint Surg Am. 92:609-618. [PubMed: 20194319]

52. Piper SL, Kim HT. Comparison of ropivacaine and bupivacaine toxicity in human articular chondrocytes. J Bone Joint Surg Am. 2008; 90:986-991. [PubMed: 18451389]

53. de Silva M, Hazleman BL, Thomas DP, Wraight P. Liposomes in arthritis: a new approach. Lancet. 1979; 1:1320-1322. [PubMed: 87780]

54. Bonanomi MH, et al. Studies of pharmacokinetics and therapeutic effects of glucocorticoids entrapped in liposomes after intraarticular application in healthy rabbits and in rabbits with antigen-induced arthritis. Rheumatol Int. 1987; 7:203-212. [PubMed: 3423619] 
55. Thakkar H, Kumar Sharma R, Murthy RS. Enhanced retention of celecoxib-loaded solid lipid nanoparticles after intra-articular administration. Drugs R D. 2007; 8:275-285. [PubMed: 17767393]

56. Horisawa E, et al. Prolonged anti-inflammatory action of DL-lactide/glycolide copolymer nanospheres containing betamethasone sodium phosphate for an intra-articular delivery system in antigen-induced arthritic rabbit. Pharm Res. 2002; 19:403-410. [PubMed: 12033371]

57. Liggins RT, et al. Intra-articular treatment of arthritis with microsphere formulations of paclitaxel: biocompatibility and efficacy determinations in rabbits. Inflamm Res. 2004; 53:363-372. [PubMed: 15316667]

58. Higaki M, Ishihara T, Izumo N, Takatsu M, Mizushima Y. Treatment of experimental arthritis with poly(D, L-lactic/glycolic acid) nanoparticles encapsulating betamethasone sodium phosphate. Ann Rheum Dis. 2005; 64:1132-1136. [PubMed: 15695536]

59. Tuncay $\mathrm{M}$, et al. In vitro and in vivo evaluation of diclofenac sodium loaded albumin microspheres. J Microencapsul. 2000; 17:145-155. [PubMed: 10738690]

60. Liang LS, Wong W, Burt HM. Pharmacokinetic study of methotrexate following intra-articular injection of methotrexate loaded poly(L-lactic acid) microspheres in rabbits. J Pharm Sci. 2005; 94:1204-1215. [PubMed: 15858840]

61. Thakkar H, Sharma RK, Mishra AK, Chuttani K, Murthy RS. Celecoxib incorporated chitosan microspheres: in vitro and in vivo evaluation. J Drug Target. 2004; 12:549-557. [PubMed: 15621680]

62. Floss DM, Schallau K, Rose-John S, Conrad U, Scheller J. Elastin-like polypeptides revolutionize recombinant protein expression and their biomedical application. Trends Biotechnol. 28:37-45. [PubMed: 19897265]

63. Shamji MF, et al. Synthesis and characterization of a thermally-responsive tumor necrosis factor antagonist. J Control Release. 2008; 129:179-186. [PubMed: 18547669]

64. Shamji MF, et al. Development and characterization of a fusion protein between thermally responsive elastin-like polypeptide and interleukin-1 receptor antagonist: sustained release of a local antiinflammatory therapeutic. Arthritis Rheum. 2007; 56:3650-3661. [PubMed: 17968946]

65. Chatzopoulos D, Moralidis E, Markou P, Makris V. Yttrium-90 radiation synovectomy in knee osteoarthritis: a prospective assessment at 6 and 12 months. Nucl Med Commun. 2009; 30:472479. [PubMed: 19357547]

66. Dos Santos MF, et al. Effectiveness of radiation synovectomy with Yttrium-90 and Samarium-153 particulate hydroxyapatite in rheumatoid arthritis patients with knee synovitis: a controlled, randomized, double-blinded trial. Clin Rheumatol. 30:77-85. [PubMed: 21120562]

67. Sojan S, Bartholomeusz D. Cutaneous radiation necrosis as a complication of yttrium-90 synovectomy. Hell J Nucl Med. 2005; 8:58-59. [PubMed: 15886756]

68. Kavakli K, et al. Long-term evaluation of chromosomal breakages after radioisotope synovectomy for treatment of target joints in patients with haemophilia. Haemophilia. 16:474-478. [PubMed: 20050929]

69. Evans $\mathrm{CH}$, et al. Gene transfer to human joints: progress toward a gene therapy of arthritis. Proc Natl Acad Sci U S A. 2005; 102:8698-8703. [PubMed: 15939878]

70. Evans CH, Gouze E, Gouze JN, Robbins PD, Ghivizzani SC. Gene therapeutic approaches-transfer in vivo. Adv Drug Deliv Rev. 2006; 58:243-258. [PubMed: 16563557]

71. Evans CH, Ghivizzani SC, Robbins PD. Arthritis gene therapy's first death. Arthritis Res Ther. 2008; 10:110. [PubMed: 18510784]

72. Evans CH, Ghivizzani SC, Robbins PD. Getting arthritis gene therapy into the clinic. Nat Rev Rheumatol. 2011; 7:244-249. [PubMed: 21135882]

73. Noth U, Steinert AF, Tuan RS. Technology insight: adult mesenchymal stem cells for osteoarthritis therapy. Nat Clin Pract Rheumatol. 2008; 4:371-380. [PubMed: 18477997]

74. Qi Y, Feng G, Yan W. Mesenchymal stem cell-based treatment for cartilage defects in osteoarthritis. Mol Biol Rep. 39:5683-5689. [PubMed: 22183306]

75. Coleman CM, Curtin C, Barry FP, O'Flatharta C, Murphy JM. Mesenchymal stem cells and osteoarthritis: remedy or accomplice? Hum Gene Ther. 21:1239-1250. [PubMed: 20649459] 
76. Murphy JM, Fink DJ, Hunziker EB, Barry FP. Stem cell therapy in a caprine model of osteoarthritis. Arthritis Rheum. 2003; 48:3464-3474. [PubMed: 14673997]

77. Guercio A, et al. Production of canine mesenchymal stem cells from adipose tissue and their application in dogs with chronic osteoarthritis of the humeroradial joints. Cell Biol Int. 36:189194. [PubMed: 21936851]

78. Diekman BO, et al. Intra-articular delivery of purified mesenchymal stem cells from C57BL/6 or MRL/MpJ superhealer mice prevents post-traumatic arthritis. Cell Transplant.

79. Davatchi F, Abdollahi BS, Mohyeddin M, Shahram F, Nikbin B. Mesenchymal stem cell therapy for knee osteoarthritis. Preliminary report of four patients. Int J Rheum Dis. 2011; 14:211-215. [PubMed: 21518322]

80. Simkin PA, Bassett JE. Pathways of microvascular permeability in the synovium of normal and diseased human knees. J Rheumatol. 2011; 38:2635-2642. [PubMed: 22045843]

81. US National Library of Medicine. ClinicalTrials.gov [online]. 2007. http://clinicaltrials.gov/ct2/ show/NCT00522184?term $=00522184 \&$ rank $=1$

82. US National Library of Medicine. ClinicalTrials.gov [online]. 2008. http://clinicaltrials.gov/ct2/ show/NCT00678782?term $=00678782$ \&rank $=1$

83. Fiocco U, et al. Synovial biomarkers in psoriatic arthritis. J. Rheumatol. (Suppl.). 2012; 89:61-64. [PubMed: 22751595]

84. US National Library of Medicine. ClinicalTrials.gov [online]. 2007. http://clinicaltrials.gov/ct2/ show/NCT00521963?term $=00521963 \&$ rank=1

85. US National Library of Medicine. ClinicalTrials.gov [online]. 2010. http://clinicaltrials.gov/ct2/ show/NCT01216631?term $=01216631 \&$ rank $=1$

86. US National Library of Medicine. ClinicalTrials.gov [online]. 2011. http://clinicaltrials.gov/ct2/ show/NCT01144143?term=01144143\&rank=1

87. US National Library of Medicine. ClinicalTrials.gov [online]. 2010. http://clinicaltrials.gov/ct2/ show/NCT00819572?term=00819572\&rank=1

88. US National Library of Medicine. ClinicalTrials.gov [online]. 2013. http://clinicaltrials.gov/ct2/ show/study/NCT00332254?term $=00332254 \&$ rank $=1$

89. Kraus VB, et al. Effects of intraarticular IL1-Ra for acute anterior cruciate ligament knee injury: a randomized controlled pilot trial (NCT00332254). Osteoarthritis Cartilage. 2012; 20:271-278. [PubMed: 22273632]

90. Catterall JB, et al. Changes in serum and synovial fluid biomarkers after acute injury (NCT00332254). Arthritis Res. Ther. 2010; 12:R229. [PubMed: 21194441]

91. US National Library of Medicine. ClinicalTrials.gov [online]. 2008. http://clinicaltrials.gov/ct2/ show/NCT00110916?term=00110916\&rank=1

92. Chevalier X, et al. Intraarticular injection of anakinra in osteoarthritis of the knee: a multicenter, randomized, double-blind, placebo-controlled study. Arthritis Rheum. 2009; 61:344-352.

[PubMed: 19248129]

94. US National Library of Medicine. ClinicalTrials.gov [online]. 2012. http://clinicaltrials.gov/ct2/ show/NCT01160822?term $=01160822 \&$ rank $=1$

95. US National Library of Medicine. ClinicalTrials.gov [online]. 2010. http://clinicaltrials.gov/ct2/ show/results/NCT00456157?term $=00456157 \&$ rank $=1$

96. US National Library of Medicine. ClinicalTrials.gov [online]. 2012. http://clinicaltrials.gov/ct2/ show/NCT01133613?term $=01133613 \&$ rank $=1$

97. US National Library of Medicine. ClinicalTrials.gov [online]. 2012. http://clinicaltrials.gov/ct2/ show/NCT01111045?term $=01111045 \&$ rank $=1$

98. US National Library of Medicine. ClinicalTrials.gov [online]. 2012. http://clinicaltrials.gov/ct2/ show/NCT01066871?term $=01066871 \&$ rank $=1$

99. US National Library of Medicine. ClinicalTrials.gov [online]. 2011. http://clinicaltrials.gov/ct2/ show/NCT00911469?term=00911469\&rank=1

100. US National Library of Medicine. ClinicalTrials.gov [online]. 2011. http://clinicaltrials.gov/ct2/ show/NCT01033994?term=NCT01033994\&rank=1 
101. US National Library of Medicine. ClinicalTrials.gov [online]. 2012. http://clinicaltrials.gov/ct2/ show/study/NCT00303056?term=00303056\&rank=1

102. US National Library of Medicine. ClinicalTrials.gov [online]. 2010. http://clinicaltrials.gov/ct2/ show/NCT00599248?term=00599248\&rank=1

103. US National Library of Medicine. ClinicalTrials.gov [online]. 2012. http://clinicaltrials.gov/ct2/ show/NCT01221441?term $=01221441 \&$ rank $=1$

104. US National Library of Medicine. ClinicalTrials.gov [online]. 2013. http://clinicaltrials.gov/ct2/ show/study/NCT01671072?term $=01671072 \&$ rank $=1$

105. US National Library of Medicine. ClinicalTrials.gov [online]. 2012. http://clinicaltrials.gov/ct2/ show/NCT01500811?term $=01500811 \&$ rank $=1$

106. US National Library of Medicine. ClinicalTrials.gov [online]. 2012. http://clinicaltrials.gov/ct2/ show/NCT01207661?term $=01207661 \&$ rank $=1$

107. US National Library of Medicine. ClinicalTrials.gov [online]. 2011. http://clinicaltrials.gov/ct2/ show/NCT01227694?term=NCT01227694\&rank=1

108. US National Library of Medicine. ClinicalTrials.gov [online]. 2011. http:// www.clinicaltrials.gov/ct2/show/NCT01436058?term=NCT01436058\&rank=1

109. US National Library of Medicine. ClinicalTrials.gov [online]. 2010. http:// www.clinicaltrials.gov/ct2/show/NCT00550524?term $=00550524 \&$ rank=1

110. US National Library of Medicine. ClinicalTrials.gov [online]. 2011. http:// www.clinicaltrials.gov/ct2/show/NCT01459640?term=NCT01459640\&rank=1

111. US National Library of Medicine. ClinicalTrials.gov [online]. 2011. http:// www.clinicaltrials.gov/ct2/show/NCT01152125?term $=01152125 \&$ rank=1

112. US National Library of Medicine. ClinicalTrials.gov [online]. 2013. http:// www.clinicaltrials.gov/ct2/show/NCT01183728?term=NCT01183728\&rank=1

113. US National Library of Medicine. ClinicalTrials.gov [online]. 2011. http:// www.clinicaltrials.gov/ct2/show/NCT01499056?term=NCT01499056\&rank=1

114. US National Library of Medicine. ClinicalTrials.gov [online]. 2012. http:// www.clinicaltrials.gov/ct2/show/NCT01504464?term=NCT01504464\&rank=1

115. US National Library of Medicine. ClinicalTrials.gov [online]. 2012. http:// www.clinicaltrials.gov/ct2/show/NCT01453738?term=NCT01453738\&rank=1

116. US National Library of Medicine. ClinicalTrials.gov [online]. 2012. http:// www.clinicaltrials.gov/ct2/show/NCT01448434?term=01448434\&rank=1

117. US National Library of Medicine. ClinicalTrials.gov [online]. 2013. http:// www.clinicaltrials.gov/ct2/show/NCT01586312?term $=$ NCT01586312\&rank=1

118. US National Library of Medicine. ClinicalTrials.gov [online]. 2010. http:// www.clinicaltrials.gov/ct2/show/NCT00702741?term $=00702741 \&$ rank=1

119. US National Library of Medicine. ClinicalTrials.gov [online]. 2013. http:// www.clinicaltrials.gov/ct2/show/NCT01088191?term=NCT01088191\&rank=1

120. US National Library of Medicine. ClinicalTrials.gov [online]. 2012. http:// www.clinicaltrials.gov/ct2/show/NCT01300598?term=NCT01300598\&rank=1

121. US National Library of Medicine. ClinicalTrials.gov [online]. 2012. http:// www.clinicaltrials.gov/ct2/show/NCT01585857?term=NCT01585857\&rank=1

122. US National Library of Medicine. ClinicalTrials.gov [online]. 2012. http:// www.clinicaltrials.gov/ct2/show/NCT01739504?term=01739504\&rank=1

123. US National Library of Medicine. ClinicalTrials.gov [online]. 2012. http:// www.clinicaltrials.gov/ct2/show/NCT01601951?term $=01601951 \&$ rank=1

124. US National Library of Medicine. ClinicalTrials.gov [online]. 2012. http:// www.clinicaltrials.gov/ct2/show/study/NCT01485198?term $=01485198 \&$ rank $=1$

125. US National Library of Medicine. ClinicalTrials.gov [online]. 2011. http:// www.clinicaltrials.gov/ct2/show/NCT01076673?term=01076673\&rank=1

126. International Simposium Intra Articular Treatment 2013 isiat.it [online]. 2013 http://www.isiat.it/.

127. Foy BD, Blake J. Diffusion of paramagnetically labeled proteins in cartilage: enhancement of the 1-D NMR imaging technique. J. Magn. Reson. 2001; 148:126-134. [PubMed: 11133285] 
128. Blyth T, Hunter JA, Stirling A. Pain relief in the rheumatoid knee after steroid injection: a singleblind comparison of hydrocortisone succinate, and triamcinolone acetonide or hexacetonide. $\mathrm{Br}$. J. Rheumatol. 1994; 33:461-463. [PubMed: 8173851]

129. Bird HA, Ring EFJ, Bacon PA. A thermographic and clinical comparison of three intra-articular steroid preparations in rheumatoid arthritis. Ann. Rheum. Dis. 1979; 38:36-39. [PubMed: 373651]

130. Marshall KW. Intra-articular hyaluronan therapy. Curr. Opin. Rheumatol. 2000; 12:468-474. [PubMed: 10990189]

131. Marcelino J, et al. CACP, encoding a secreted proteoglycan, is mutated in camptodactylylarthropathy-coxa vara- pericarditis syndrome. Nat. Genet. 1999; 23:319-322. [PubMed: 10545950]

132. Coles JM, et al. Loss of cartilage, stiffness and frictional properties in mice lacking Pgr4. Arthritis Rheum. 2010; 62:1666-1674. [PubMed: 20191580]

133. Jay GD, et al. Prevention of cartilage degeneration and restoration of chondroprotection by lubricin tribosupplementation in the rat following ACL transection. Arthritis Rheum. 2010; 62:2382-2391. [PubMed: 20506144]

134. Sheth U, et al. Efficacy of autologous platelet-rich plasma use for orthopaedic indications: a metaanalysis. J. Bone Joint Surg.. Am. 2012; 94:298-307. [PubMed: 22241606]

135. Burt HM, Tsallas A, Gilchrist S, Liang LS. Intra-articular drug delivery systems: Overcoming the shortcomings of joint disease therapy. Expert Opin. Drug Deliv. 2009; 6:17-26. [PubMed: 19236205]

136. Presumey J, et al. PLGA microspheres encapsulating siRNA anti-TNFalpha: efficient RNAimediated treatment of arthritic joints. Eur. J. Pharm. Biopharm. 2012; 82:457-464. [PubMed: 22922428]

137. Bodick N, et al. FX006 prolongs the residency of triamcinolone acetonide in the synovial tissues of patients with knee osteoarthritis. Osteoarthritis Cart. 2013; 21(Suppl.):S144-S145.

138. Rodriguez-Merchan EC. Aspects of current management: orthopaedic surgery in haemophilia. Haemophilia. 2011; 18:8-16. [PubMed: 21535324]

139. Barry F, Murphy M. Mesenchymal stem cells in joint disease and repair Nat. Rev. Rheumatol. http://dx.doi.org/10.1038/nrrheum.2013.109.

140. Woodell-May J, et al. Autologous protein solution inhibits MMP-13 production by IL-1 $\beta$ and TNF-a-stimulated human articular chondrocytes. J. Orthop. Res. 2011; 29:1320-1326. [PubMed: 21437966]

141. Ha CW, Noh MJ, Choi KB, Lee KH. Initial phase I safety of retrovirally transduced human chondrocytes expressing transforming growth factor-b-1 in degenerative arthritis patients. Cytotherapy. 2012; 14:247-256. [PubMed: 22242865]

142. Ha CW, et al. Efficacy of TissueGene-C (TG-C), a cell mediated gene therapy, in patients with osteoarthritis: a phase IIa clinical study. J Tissue Eng Regen Med. 2012; 6(Suppl1):287. Abstract 48.05 . 


\section{Key points}

- Getting therapeutics into joints in a targeted and sustained fashion is difficult

- Intra-articular injection solves the delivery problem and brings several additional advantages over systemic administration, including increased bioavailability, reduced systemic exposure, fewer off-target effects and lower costs

- Soluble drugs exit joints very rapidly via the capillaries (in the case of small molecules) and lymphatic system (for macromolecules)

- Strategies for extending the intra-articular half-lives of therapeutics include the use of small particles, drug modification, and gene transfer

- Delivery of hyaluronate and corticosteroids accounts for the majority of intraarticular injections; additional therapeutics include recombinant proteins, autologous blood products and analgesics

- Clinical trials involving the intra-articular injection of mesenchymal stem cells have multiplied enormously in recent years 


\section{Review criteria}

PubMed served as the primary database, initially using the search terms "intra-articular and therapy". No year limitations were imposed. The list of articles was screened by title for articles in English, with a bias towards articles that were recent, clinical and novel. Non-clinical articles were included if they provided mechanistic insight or supplied preclinical advances. The abstracts of the selected articles were then read to identify relevant papers that were down-loaded and studied in detail. More focused searches were then conducted using search terms "intra-articular and steroid", "intra-articular and hyaluronan", "intra-articular and protein", "intra-articular and cell" and "intra-articular and osteoarthritis and therapy". Because the authors do research in the area of intraarticular therapy, they were able to identify additional references from their working knowledge of the field. ClinicalTrials.gov was searched to provide the information given in Tables 1 and 2. 


\section{Box 1 | Drugs approved by the FDA for intra-articular administration}

\section{Corticosteroids}

Hydrocortisone tebutate (Hydrocortone-TBA)

Betamethasone acetate;betamethasone sodium phosphate (Celestone Soluspan)

Methylprednisone acetate (Depo-Medrol)

Triamcinolone acetonide (Kenalog-40)

Triamcinolone diacetate (Aristocort Forte)

Triamcinolone hexacetonide (Aristospan)

Dexamethasone sodium phosphate

Hyaluronic acids

Synvisc

Synvisc-one*

Hyalgan

Supartz

OrthoVisc

Euflexxa (previously Nuflexxa)

\section{Gel-One*}

*These products are crosslinked preparations and are delivered as a single intra-articular injection; others require 3-5 doses

Various analgesics 


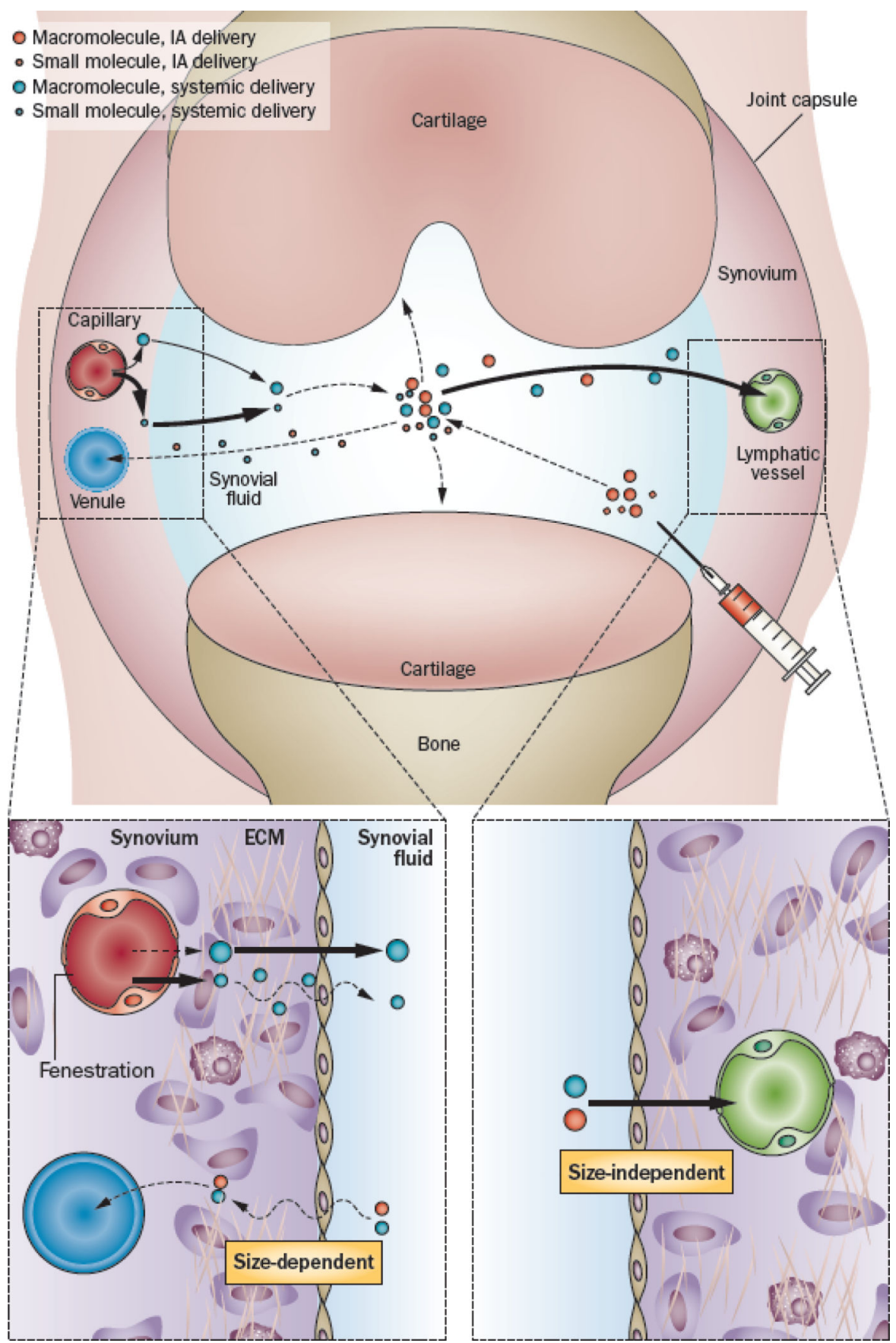

Figure 1.

How soluble molecules get into and out of joints. Macromolecules in the circulation enter the joint via the synovial capillaries and are sieved by the fenestrated endothelium of the capillaries (see figure 2). Small molecules also enter via the capillaries, but the major resistance to their entry is provided by the ECM of the synovial interstitum. Intra-articular injection by-passes both of these constraints to entry. However, both large and small molecules rapidly exit the joint via the lymphatics and small blood vessels, respectively 


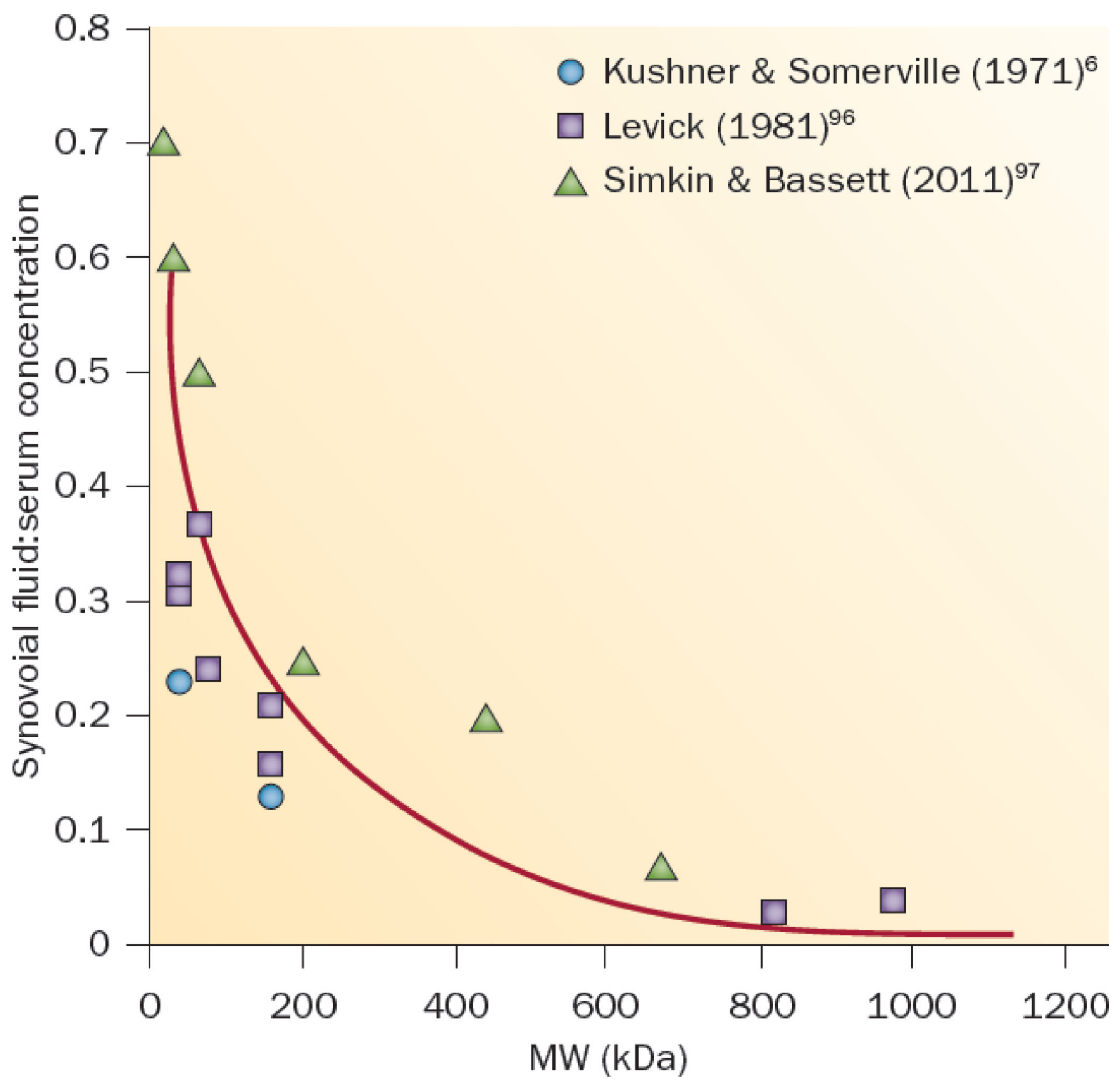

Figure 2.

Concentration ratios of proteins between serum and synovial fluid. Entry of macromolecules into the synovial fluid from the systemic circulation is normally impeded as a function of molecular size (see also Figure 1) 
Table 1

Trials of recombinant proteins and synthesized peptides delivered by intra-articular injection

\begin{tabular}{|c|c|c|c|c|}
\hline $\begin{array}{l}\text { Study name; } \\
\text { ClinicalTrials.gov } \\
\text { identifier }\end{array}$ & $\begin{array}{l}\text { Drug* and } \\
\text { comparator }\end{array}$ & Indication & $\begin{array}{l}\text { Study phase; } \\
\text { design }\end{array}$ & $\begin{array}{l}\text { Current status; results } \\
\text { reported }{ }^{*}\end{array}$ \\
\hline $\begin{array}{l}\text { Intra-Articular Injection of } \\
\text { Etanercept in Patient } \\
\text { Suffering From Rheumatoid } \\
\text { Arthritis: a Double-Blind } \\
\text { Randomized Study; } \\
\text { NCT0052218498 }\end{array}$ & Etanercept vs steroid & RA & $\begin{array}{l}\text { Phase III; } \\
\text { Double-blind } \\
\text { RCT }\end{array}$ & $\begin{array}{l}\text { Completed Nov 2006; no } \\
\text { results reported }\end{array}$ \\
\hline $\begin{array}{l}\text { Evaluation of The Efficacy } \\
\text { And Safety of Intra- } \\
\text { Articular Etanercept in } \\
\text { Patients With Refractory } \\
\text { Knee Joint Synovitis; } \\
\text { NCT00678782 }\end{array}$ & Etanercept vs placebo & $\begin{array}{l}\text { Refractory knee-joint } \\
\text { synovitis: RA, PsA and SpA }\end{array}$ & $\begin{array}{l}\text { Phase II; single- } \\
\text { blind RCT }\end{array}$ & $\begin{array}{l}\text { Completed Dec 2007; no } \\
\text { results posted (associated } \\
\text { biomarker study } \\
\text { published }^{100} \text { ) }\end{array}$ \\
\hline $\begin{array}{l}\text { Intraarticular Injection of } \\
\text { Infliximab; } \\
\text { NCT00521963 }\end{array}$ & Infliximab vs corticosteroid & $\begin{array}{l}\text { Monoarthritis of the knee, or } \\
\text { residual knee inflammation } \\
\text { in controlled polyarthritis }\end{array}$ & $\begin{array}{l}\text { Phase II/III; } \\
\text { double-blind } \\
\text { RCT }\end{array}$ & $\begin{array}{l}\text { Recruitment status } \\
\text { unknown, last update Aug } \\
2007\end{array}$ \\
\hline $\begin{array}{l}\text { Seronegative Oligoarthritis } \\
\text { of the Knee Study (SOKS); } \\
\text { NCT01216631 } 102\end{array}$ & $\begin{array}{l}\text { IA vs IV infliximab vs } \\
\text { methylprednisolone }\end{array}$ & $\mathrm{SpA}$ & $\begin{array}{l}\text { Phase II; } \\
\text { double-blind } \\
\text { RCT }\end{array}$ & $\begin{array}{l}\text { Recruitment status } \\
\text { unknown, no updates since } \\
\text { record created in } 2010\end{array}$ \\
\hline $\begin{array}{l}\text { Treatment Of Knee } \\
\text { Osteoarthritis With Intra- } \\
\text { Articular Infliximab; } \\
\text { NCT01144143 }\end{array}$ & $\begin{array}{l}\text { Infliximab vs } \\
\text { methylprednisolone vs } \\
\text { placebo }\end{array}$ & Knee OA & $\begin{array}{l}\text { Phase IV; } \\
\text { double-blind } \\
\text { RCT }\end{array}$ & $\begin{array}{l}\text { Completed Dec 2010; no } \\
\text { results posted }\end{array}$ \\
\hline $\begin{array}{l}\text { Study of Intra-articular } \\
\text { DLX105 Applied to } \\
\text { Patients With Severely } \\
\text { Painful Osteoarthritis of the } \\
\text { Knee; NCT00819572 }\end{array}$ & DLX $105^{\S}$ vs placebo & Severely painful knee OA & $\begin{array}{l}\text { Phase I/IIa; } \\
\text { double-blind } \\
\text { RCT }\end{array}$ & $\begin{array}{l}\text { Completed Sep 2010; no } \\
\text { results posted }\end{array}$ \\
\hline $\begin{array}{l}\text { Study to Prevent Cartilage } \\
\text { Damage Following Acute } \\
\text { Knee Injury; } \\
\text { NCT00332254 }\end{array}$ & Anakinra vs placebo & Severe knee injury & $\begin{array}{l}\text { Phase I/II; } \\
\text { double-blind } \\
\text { RCT }\end{array}$ & $\begin{array}{l}\text { Completed Jun } 2007 \text {; } \\
\text { temporary improvement in } \\
\text { KOOS score }^{46}\end{array}$ \\
\hline $\begin{array}{l}\text { Treatment for Patients With } \\
\text { Osteoarthritis (OA) of the } \\
\text { Knee; NCT00110916 }\end{array}$ & Anakinra vs placebo & Painful knee OA & $\begin{array}{l}\text { Phase II; } \\
\text { double-blind } \\
\text { RCT }\end{array}$ & $\begin{array}{l}\text { Completed Feb } 2005 \text {; } \\
\text { results published (anakinra } \\
\text { not better than placebo) }\end{array}$ \\
\hline $\begin{array}{l}\text { To Determine the Safety, } \\
\text { Tolerability, } \\
\text { Pharmacokinetics and } \\
\text { Effect on Pain of a Single } \\
\text { Intra-articular } \\
\text { Administration of } \\
\text { Canakinumab in Patients } \\
\text { With Osteoarthritis in the } \\
\text { Knee; NCT01160822 }\end{array}$ & $\begin{array}{l}\text { Canakinumab vs placebo } \\
\text { injection, with or without } \\
\text { oral naproxen vs oral } \\
\text { placebo }\end{array}$ & Mild-to-moderate knee OA & $\begin{array}{l}\text { Phase II; } \\
\text { double-blind } \\
\text { RCT }\end{array}$ & $\begin{array}{l}\text { Completed; raw results } \\
\text { posted Sep 2012, no } \\
\text { analysis available }\end{array}$ \\
\hline $\begin{array}{l}\text { A Phase 1, Double-Blind, } \\
\text { Randomized, Single Dose } \\
\text { Escalation Safety Study of } \\
\text { Intra-articular OP-1 in } \\
\text { Subjects With Osteoarthritis } \\
\text { of the Knee (Knee OA); } \\
\text { NCT00456157 }\end{array}$ & BMP7 vs placebo & Knee OA & $\begin{array}{l}\text { Phase I; double- } \\
\text { blind RCT }\end{array}$ & $\begin{array}{l}\text { Completed; results } \\
\text { published (support } \\
\text { continued development) }^{48}\end{array}$ \\
\hline $\begin{array}{l}\text { Double-Blind, Randomized, } \\
\text { Single Dose Escalation } \\
\text { Safety Study of } \\
\text { Intraarticular Bone } \\
\text { Morphogenic Protein (38A } \\
\text { BMP-7) in Subjects With } \\
\text { Osteoarthritis (OA) of the } \\
\text { Knee; NCT01133613 }\end{array}$ & BMP7 vs placebo & Knee OA & $\begin{array}{l}\text { Phase I; double- } \\
\text { blind RCT }\end{array}$ & $\begin{array}{l}\text { Completed Oct 2011; no } \\
\text { results posted }\end{array}$ \\
\hline
\end{tabular}




\begin{tabular}{|c|c|c|c|c|}
\hline $\begin{array}{l}\text { Study name; } \\
\text { ClinicalTrials.gov } \\
\text { identifier }\end{array}$ & $\begin{array}{l}\text { Drug* and } \\
\text { comparator }\end{array}$ & Indication & $\begin{array}{l}\text { Study phase; } \\
\text { design }\end{array}$ & $\begin{array}{l}\text { Current status; results } \\
\text { reported }^{\ddagger}\end{array}$ \\
\hline $\begin{array}{l}\text { Dose Finding Study of } \\
\text { Bone Morphogenetic } \\
\text { Protein } 7 \text { (BMP-7) in } \\
\text { Subjects With Osteoarthritis } \\
\text { (OA) of the Knee; } \\
\text { NCT01111045 }\end{array}$ & BMP7 vs placebo & Knee OA & $\begin{array}{l}\text { Phase II; } \\
\text { double-blind } \\
\text { RCT }\end{array}$ & $\begin{array}{l}\text { Completed Aug 2011; no } \\
\text { results posted }\end{array}$ \\
\hline $\begin{array}{l}\text { AS902330 in Cartilage } \\
\text { Injury Repair (CIR); } \\
\text { NCT01066871 } 109\end{array}$ & FGF18 vs placebo & $\begin{array}{l}\text { Acute injury of knee } \\
\text { cartilage }\end{array}$ & $\begin{array}{l}\text { Phase II; } \\
\text { double-blind } \\
\text { RCT }\end{array}$ & $\begin{array}{l}\text { Ongoing, recruitment } \\
\text { ended, no estimated } \\
\text { completion date }\end{array}$ \\
\hline $\begin{array}{l}\text { Study of AS902330 } \\
\text { (rhFGF-18) Administered } \\
\text { Intra-articularly in Patients } \\
\text { With Knee Primary } \\
\text { Osteoarthritis Who Are } \\
\text { Candidates for Total Knee } \\
\text { Replacement; } \\
\text { NCT00911469110 }\end{array}$ & FGF18 vs placebo & Knee OA eligible for TJR & $\begin{array}{l}\text { Phase I; double- } \\
\text { blind RCT }\end{array}$ & $\begin{array}{l}\text { Completed Jun 2010; no } \\
\text { results posted }\end{array}$ \\
\hline $\begin{array}{l}\text { A Multicenter Study of } \\
\text { rhFGF } 18 \text { in Patients With } \\
\text { Knee Osteoarthritis Not } \\
\text { Requiring Surgery; } \\
\text { NCT01033994111 }\end{array}$ & FGF18 vs placebo & $\begin{array}{l}\text { Knee OA not requiring } \\
\text { surgery }\end{array}$ & $\begin{array}{l}\text { Phase I; double- } \\
\text { blind RCT }\end{array}$ & $\begin{array}{l}\text { Data collection completed } \\
\text { no results posted }\end{array}$ \\
\hline $\begin{array}{l}\text { A Study to Investigate the } \\
\text { Safety and Effectiveness of } \\
\text { Different Doses of } \\
\text { Sprifermin (AS902330) in } \\
\text { Patients With Osteoarthritis } \\
\text { of the Knee (FORWARD); } \\
\text { NCT01919164112 }\end{array}$ & FGF18 vs placebo & Knee OA & $\begin{array}{l}\text { Phase II; } \\
\text { double-blind } \\
\text { RCT }\end{array}$ & Recruiting patients \\
\hline $\begin{array}{l}\text { A Multicenter trial of } \\
\text { AS902330 (Recombinant } \\
\text { Human Fibroblast Growth } \\
\text { Factor-18) or Placebo After } \\
\text { Microfracture Surgery for } \\
\text { Cartilage Injury of the } \\
\text { Knee; NCT01689337113 }\end{array}$ & FGF18 vs placebo & $\begin{array}{l}\text { Microfracture of the femoral } \\
\text { articular surfaces with intact } \\
\text { subchondral bone }\end{array}$ & $\begin{array}{l}\text { Phase II; } \\
\text { double-blind } \\
\text { RCT }\end{array}$ & Recruiting patients \\
\hline $\begin{array}{l}\text { Efficacy and Safety Study } \\
\text { of Intra-articular Multiple } \\
\text { Doses of Icatibant in } \\
\text { Patients With Painful Knee } \\
\text { Osteoarthritis; } \\
\text { NCT00303056 }\end{array}$ & Icatibant//vs placebo & Knee OA & $\begin{array}{l}\text { Phase II; } \\
\text { double-blind } \\
\text { RCT }\end{array}$ & $\begin{array}{l}\text { Completed Jul 2007; no } \\
\text { results posted }\end{array}$ \\
\hline
\end{tabular}

*

IA delivery unless stated otherwise.

*As of September 2013.

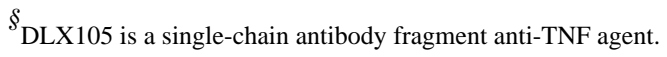

/Icatibant is a chemically-synthesized 10-amino acid peptide antagonist of bradykinin B2 receptors.

Abbreviations: ACL, anterior cruciate ligament; BMP7, bone morphogenic protein 7 (also known as osteogenic protein 1); FGF18, fibroblast growth factor 18; IA, intra-articular; IV, intravenous; KOOS, knee injury and osteoarthritis outcome score; OA, osteoarthritis; PsA, psoriatic arthritis; RA, rheumatoid arthritis; RCT, randomized controlled trial; SpA, spondyloarthritis; TJR, total joint replacement. 
Table 2

Clinical trials involving the intra-articular injection of cells

\begin{tabular}{|c|c|c|c|c|}
\hline $\begin{array}{l}\text { Study name; } \\
\text { ClinicalTrials.gov } \\
\text { identifier }\end{array}$ & Cell type and source & Indication & Study phase; design & $\begin{array}{l}\text { Current status; }{ }^{*} \text { results } \\
\text { reported }\end{array}$ \\
\hline $\begin{array}{l}\text { Clinical Trial to Assess } \\
\text { the Safety, Feasibility, } \\
\text { and Efficacy of } \\
\text { Transferring a } \\
\text { Potentially Anti- } \\
\text { arthritic Cytokine Gene } \\
\text { to Human Joints with } \\
\text { Rheumatoid Arthritis; } \\
\text { NIH OBA number: } \\
9406074^{\ddagger}\end{array}$ & $\begin{array}{l}\text { Autologous synovial cells (transduced to } \\
\text { express IL-1Ra) }\end{array}$ & RA & Phase I; open label & Completed; results published ${ }^{84}$ \\
\hline $\begin{array}{l}\text { Safety Study of } \\
\text { TissueGene-C in } \\
\text { Degenerative Joint } \\
\text { Disease of the Knee } \\
\text { (TGC-03-01); } \\
\text { NCT00599248 }\end{array}$ & $\begin{array}{l}\text { Chondrocyte, allogeneic (transduced to } \\
\text { express TGF- } \beta_{1} \text { ) }\end{array}$ & $\begin{array}{l}\text { Knee OA scheduled for } \\
\text { TKA }\end{array}$ & $\begin{array}{l}\text { Phase I; single-blind } \\
\text { RCT }\end{array}$ & $\begin{array}{l}\text { Completed May 2010; results } \\
\text { published }^{116}\end{array}$ \\
\hline $\begin{array}{l}\text { Study of TG-C in } \\
\text { Patients With Grade } 3 \\
\text { Degenerative Joint } \\
\text { Disease of the Knee; } \\
\text { NCT01221441 }\end{array}$ & $\begin{array}{l}\text { Chondrocyte, allogeneic (transduced to } \\
\text { express TGF- } \beta_{1} \text { ) }\end{array}$ & Knee OA, KLG III & $\begin{array}{l}\text { Phase II; double- } \\
\text { blind RCT }\end{array}$ & $\begin{array}{l}\text { Ongoing, recruitment ended, } \\
\text { estimated completion date Oct } \\
2014\end{array}$ \\
\hline $\begin{array}{l}\text { Efficacy and Safety } \\
\text { Study of TissueGene-C } \\
\text { to Degenerative } \\
\text { Arthritis; } \\
\text { NCT01671072 } 118\end{array}$ & $\begin{array}{l}\text { Chondrocyte, allogeneic (transduced to } \\
\text { express TGF- } \beta_{1} \text { ) }\end{array}$ & Knee OA, KLG II-III & $\begin{array}{l}\text { Phase II; single- } \\
\text { blind RCT }\end{array}$ & $\begin{array}{l}\text { Completed Jan 2013; abstract } \\
\text { published }^{119}\end{array}$ \\
\hline $\begin{array}{l}\text { Autologous } \\
\text { Chondrocyte Intra- } \\
\text { articular Implantation } \\
\text { in Patients With Severe } \\
\text { Hip Osteoarthritis; } \\
\text { NCT01500811 }\end{array}$ & Chondrocyte, autologous & Severe hip OA & Phase I; open label & $\begin{array}{l}\text { Unknown; estimated } \\
\text { completion date Aug } 2013\end{array}$ \\
\hline $\begin{array}{l}\text { Adult Stem Cell } \\
\text { Therapy for Repairing } \\
\text { Articular Cartilage in } \\
\text { Gonarthrosis; } \\
\text { NCT01227694 } \\
122\end{array}$ & MSC, autologous, bone-marrow-derived & Knee OA & $\begin{array}{l}\text { Phase I/II; open } \\
\text { label }\end{array}$ & $\begin{array}{l}\text { Study completed; no study } \\
\text { results posted }\end{array}$ \\
\hline $\begin{array}{l}\text { Side Effects of } \\
\text { Autologous } \\
\text { Mesenchymal Stem } \\
\text { Cell Transplantation in } \\
\text { Ankle Joint } \\
\text { Osteoarthritis; } \\
\text { NCT01436058 }\end{array}$ & MSC, autologous, bone-marrow-derived & Ankle joint OA & Phase I; open label & $\begin{array}{l}\text { Completed Sep 2011; no } \\
\text { results posted }\end{array}$ \\
\hline $\begin{array}{l}\text { Stem Cell } \\
\text { Transplantation for the } \\
\text { Treatment of Knee } \\
\text { Osteoarthritis; } \\
\text { NCT00550524 }\end{array}$ & MSC, autologous, bone-marrow-derived & Knee OA & Phase I; open label & Recruiting by invitation \\
\hline $\begin{array}{l}\text { Intra-Articular } \\
\text { Autologous Bone } \\
\text { Marrow Mesenchymal } \\
\text { Stem Cells }\end{array}$ & MSC, autologous, bone-marrow-derived & Mild-to-moderate knee OA & $\begin{array}{l}\text { Phase II; open label, } \\
\text { active comparator: } \\
\text { hyaluronic acid }\end{array}$ & $\begin{array}{l}\text { Recruiting, estimated } \\
\text { completion date Mar } 2014\end{array}$ \\
\hline
\end{tabular}




\begin{tabular}{|c|c|c|c|c|}
\hline $\begin{array}{l}\text { Study name; } \\
\text { ClinicalTrials.gov } \\
\text { identifier }\end{array}$ & Cell type and source & Indication & Study phase; design & $\begin{array}{l}\text { Current status; }{ }^{*} \text { results } \\
\text { reported }\end{array}$ \\
\hline \multicolumn{5}{|l|}{$\begin{array}{l}\text { Transplantation to } \\
\text { Treat Mild to Moderate } \\
\text { Osteoarthritis; } \\
\text { NCT01459640 }\end{array}$} \\
\hline $\begin{array}{l}\text { Safety and Efficacy of } \\
\text { Autologous Bone } \\
\text { Marrow Stem Cells for } \\
\text { Treating Osteoarthritis; } \\
\text { NCT01152125 }\end{array}$ & MSC, autologous, bone-marrow-derived & OA, KLG III-IV & $\begin{array}{l}\text { Phase I/II; open } \\
\text { label }\end{array}$ & $\begin{array}{l}\text { Recruiting by invitation, } \\
\text { estimated completion date Jan } \\
2012\end{array}$ \\
\hline $\begin{array}{l}\text { Treatment of Knee } \\
\text { Osteoarthritis With } \\
\text { Autologous } \\
\text { Mesenchymal Stem } \\
\text { Cells (KDD\&MSV); } \\
\text { NCT01183728 }\end{array}$ & MSC, autologous, bone-marrow-derived & Knee OA, KLG II-IV & $\begin{array}{l}\text { Phase I/II; open } \\
\text { label }\end{array}$ & $\begin{array}{l}\text { Ongoing, recruitment over, } \\
\text { estimated completion date Jun } \\
2013\end{array}$ \\
\hline $\begin{array}{l}\text { Mesenchymal Stem } \\
\text { Cell Transplantation in } \\
\text { Osteoarthritis of Hip } \\
\text { Joint; NCT01499056 }\end{array}$ & MSC, autologous, bone-marrow derived & Hip OA & Phase I; open label & $\begin{array}{l}\text { Completed Mar 2011; no } \\
\text { results posted }\end{array}$ \\
\hline $\begin{array}{l}\text { The Effects of Intra- } \\
\text { articular Injection of } \\
\text { Mesenchymal Stem } \\
\text { Cells in Knee Joint } \\
\text { Osteoarthritis; } \\
\text { NCT01504464 }\end{array}$ & MSC, autologous, bone-marrow-derived & Knee OA & $\begin{array}{l}\text { Phase II; double- } \\
\text { blind RCT }\end{array}$ & $\begin{array}{l}\text { Completed Nov 2012; no } \\
\text { results posted }\end{array}$ \\
\hline $\begin{array}{l}\text { Allogeneic } \\
\text { Mesenchymal Stem } \\
\text { Cells in Osteoarthritis; } \\
\text { NCT01453738 }\end{array}$ & MSC, allogeneic, source unspecified & Knee OA & $\begin{array}{l}\text { Phase II; double- } \\
\text { blind RCT }\end{array}$ & $\begin{array}{l}\text { Ongoing, recruitment over, } \\
\text { estimated completion date Jul } \\
2014\end{array}$ \\
\hline $\begin{array}{l}\text { Allogeneic } \\
\text { Mesenchymal Stem } \\
\text { Cells for Osteoarthritis; } \\
\text { NCT01448434 }\end{array}$ & MSC, allogeneic, source unspecified & Knee OA & $\begin{array}{l}\text { Phase II; double- } \\
\text { blind RCT }\end{array}$ & $\begin{array}{l}\text { Ongoing, recruitment over, } \\
\text { estimated completion date Feb } \\
2013\end{array}$ \\
\hline $\begin{array}{l}\text { Treatment of Knee } \\
\text { Osteoarthritis With } \\
\text { Allogenic } \\
\text { Mesenchymal Stem } \\
\text { Cells (MSV_allo); } \\
\text { NCT01586312132 }\end{array}$ & MSC, allogeneic, bone-marrow-derived & Knee OA & $\begin{array}{l}\text { Phase II; double- } \\
\text { blind RCT, active } \\
\text { comparator: } \\
\text { hyaluronic acid }\end{array}$ & $\begin{array}{l}\text { Active, recruiting; estimated } \\
\text { completion date Dec } 2013\end{array}$ \\
\hline $\begin{array}{l}\text { A Phase I/II Study of } \\
\text { Chondrogen Delivered } \\
\text { by Intra-Articular } \\
\text { Injection Following } \\
\text { Meniscectomy; } \\
\text { NCT00225095 }\end{array}$ & MSC, allogeneic, source unspecified & Meniscectomy & $\begin{array}{l}\text { Phase I/II; double- } \\
\text { blind; randomized }\end{array}$ & Completed; no results posted \\
\hline $\begin{array}{l}\text { Follow-up Study of } \\
\text { Chondrogen } ® D e l i v e r e d \\
\text { by Intra-Articular } \\
\text { Injection Following } \\
\text { Meniscectomy; } \\
\text { NCT00702741 }\end{array}$ & MSC, allogeneic, source unspecified & Partial medial menisectomy & $\begin{array}{l}\text { Phase II; double- } \\
\text { blind RCT }\end{array}$ & $\begin{array}{l}\text { Recruitment status unknown, } \\
\text { last update Aug } 2010\end{array}$ \\
\hline $\begin{array}{l}\text { Safety and Efficacy } \\
\text { Study of MSB- } \\
\text { CAR001 in Subjects } 6 \\
\text { Weeks Post an Anterior } \\
\text { Cruciate Ligament } \\
\text { Reconstruction; } \\
\text { NCT01088191 }\end{array}$ & MSC, allogeneic, source unspecified & ACL reconstruction & $\begin{array}{l}\text { Phase I/II; double- } \\
\text { blind RCT, active } \\
\text { control: hyaluronan }\end{array}$ & $\begin{array}{l}\text { Ongoing, recruitment over, } \\
\text { estimated completion date Jun } \\
2014\end{array}$ \\
\hline $\begin{array}{l}\text { Autologous Adipose } \\
\text { Tissue Derived } \\
\text { Mesenchymal Stem } \\
\text { Cells Transplantation in } \\
\text { Patients With }\end{array}$ & MSC, autologous, adipose-tissue derived & Knee OA & $\begin{array}{l}\text { Phase I/II; open } \\
\text { label }\end{array}$ & $\begin{array}{l}\text { Completed Mar 2012; no } \\
\text { results posted }\end{array}$ \\
\hline
\end{tabular}




\begin{tabular}{|c|c|c|c|c|}
\hline $\begin{array}{l}\text { Study name; } \\
\text { ClinicalTrials.gov } \\
\text { identifier }\end{array}$ & Cell type and source & Indication & Study phase; design & $\begin{array}{l}\text { Current status; } \\
\text { reported }\end{array}$ \\
\hline \multicolumn{5}{|l|}{$\begin{array}{l}\text { Degenerative Arthritis; } \\
\text { NCT01300598 }\end{array}$} \\
\hline $\begin{array}{l}\text { ADIPOA - Clinical } \\
\text { Study; } \\
\text { NCT01585857 }\end{array}$ & MSC, autologous, adipose-tissue-derived & $\begin{array}{l}\text { Knee OA, moderate or } \\
\text { severe }\end{array}$ & Phase I; open label & $\begin{array}{l}\text { Active, recruiting; estimated } \\
\text { completion date Apr } 2015\end{array}$ \\
\hline $\begin{array}{l}\text { Autologous Adipose- } \\
\text { Derived Stromal Cells } \\
\text { Delivered Intra- } \\
\text { articularly in Patients } \\
\text { With Osteoarthritis; } \\
\text { NCT01739504 }{ }^{138}\end{array}$ & MSC, autologous, adipose-tissue-derived & $\mathrm{OA}$ & $\begin{array}{l}\text { Phase I/II; open } \\
\text { label }\end{array}$ & $\begin{array}{l}\text { Active, recruiting; estimated } \\
\text { completion date Dec } 2015\end{array}$ \\
\hline $\begin{array}{l}\text { Outcomes Data of Bone } \\
\text { Marrow Stem Cells to } \\
\text { Treat Hip and Knee } \\
\text { Osteoarthritis; } \\
\text { NCT01601951 }\end{array}$ & Bone-marrow concentrate, autologous & Hip and knee OA & $\begin{array}{l}\text { Phase unspecified; } \\
\text { prospective, } \\
\text { observational }\end{array}$ & $\begin{array}{l}\text { Ongoing, not recruiting, no } \\
\text { estimated completion date }\end{array}$ \\
\hline $\begin{array}{l}\text { Autologous Stem Cells } \\
\text { in Osteoarthritis; } \\
\text { NCT01485198 }\end{array}$ & Haematopoietic stem cells, autologous & Knee OA, KLG II-III & Phase I; open label & $\begin{array}{l}\text { Active, recruiting; estimated } \\
\text { completion date Aug } 2013\end{array}$ \\
\hline $\begin{array}{l}\text { Peripheral Blood- } \\
\text { drived Stem Cell Trial } \\
\text { on Damaged Knee } \\
\text { Cartilage (PBSC); } \\
\text { NCT01076673 }\end{array}$ & $\begin{array}{l}\text { Peripheral blood stem cells (identity } \\
\text { unspecified) }\end{array}$ & Damaged articular cartilage & $\begin{array}{l}\text { Phase unspecified; } \\
\text { open label }\end{array}$ & $\begin{array}{l}\text { Recruitment status unknown, } \\
\text { last update Jul } 2011\end{array}$ \\
\hline $\begin{array}{l}\text { Allogeneic } \\
\text { Mesenchymal Stem } \\
\text { Cells in Osteoarthritis; } \\
\text { NCT01453738 } 142\end{array}$ & MSC, source unspecified, allogeneic & Knee OA, KLG II-III & $\begin{array}{l}\text { Phase II; double } \\
\text { blind }\end{array}$ & $\begin{array}{l}\text { Ongoing, not recruiting, } \\
\text { estimated completion date } \\
\text { July } 2014\end{array}$ \\
\hline $\begin{array}{l}\text { Autologous Adipose } \\
\text { Tissue Derived } \\
\text { Mesenchymal } \\
\text { Progenitor Cells } \\
\text { Therapy for Patients } \\
\text { With Knee } \\
\text { Osteoarthritis; } \\
\text { NCT01809769 }\end{array}$ & $\begin{array}{l}\text { Mesenchymal progenitor cells, } \\
\text { autologous, adipose-tissue-derived }\end{array}$ & Knee OA & $\begin{array}{l}\text { Phase I/II; double } \\
\text { blind }\end{array}$ & $\begin{array}{l}\text { Ongoing, not recruiting, } \\
\text { estimated completion date } \\
\text { October } 2013\end{array}$ \\
\hline $\begin{array}{l}\text { Autologous Bone } \\
\text { Marrow Mesenchymal } \\
\text { Stem Cells } \\
\text { Transplantation for } \\
\text { Articular Cartilage } \\
\text { Defects Repair; } \\
\text { NCT01895413 }\end{array}$ & MSC, bone marrow, autologous & Knee OA & $\begin{array}{l}\text { Phase I/II; open } \\
\text { label }\end{array}$ & Recruiting \\
\hline $\begin{array}{l}\text { Transplantation of } \\
\text { Bone Marrow Derived } \\
\text { mesenchymal Stem } \\
\text { Cells in Affected Knee } \\
\text { Osteoarthritis by } \\
\text { Rheumatoid Arthritis } \\
\text { (sic); NCT01873625 }\end{array}$ & $\begin{array}{l}\text { MSC, bone marrow, not stated whether } \\
\text { autologous or allogeneic. }\end{array}$ & Knee OA & $\begin{array}{l}\text { Phase II/III; } \\
\text { randomized, open- } \\
\text { label }\end{array}$ & Completed; no results posted \\
\hline $\begin{array}{l}\text { Safety and Efficacy } \\
\text { Study of MSB- } \\
\text { CAR001 in Subjects } 6 \\
\text { Weeks Post an Anterior } \\
\text { Cruciate Ligament } \\
\text { Reconstruction; } \\
\text { NCT01088191 }\end{array}$ & MSC, source unspecified & Knee, ACL injury & $\begin{array}{l}\text { Phase I/II; double } \\
\text { blind RCT }\end{array}$ & $\begin{array}{l}\text { Ongoing, not recruiting. } \\
\text { Estimated completion date, } \\
\text { June } 2014\end{array}$ \\
\hline
\end{tabular}


Abbreviations: ACL, anterior cruciate ligament; KLG, Kellgren-Lawrence grade; MSC, mesenchymal stem cell; OA, osteoarthritis; RCT, randomized controlled trial; TGF- $\beta_{1}$, transforming growth factor $\beta_{1}$; TKA, total knee arthroplasty. 